\title{
ANALISIS KOMPARASI MANAJEMEN RISIKO PADA KOPERASI SYARIAH DI KABUPATEN BOYOLALI
}

\author{
Abdul Haris Romdhoni \\ STIE-AAS Surakarta \\ harisromdhoni27@yahoo.com
}

\begin{abstract}
This study aims to determine the risk of what is on of financing in Islamic financial institutions in Boyolali especially sharia cooperatives and how to handle them. This research is a descriptive study using primary data obtained from interviews, excavation documentation and supporting information as well as a qualitative research.

Mudaraba is a contract and products of Islamic institution. Mudaraba of financing is one of a number of financing in Islamic financial institutions that have a high risk. With such high risk need careful risk management so that losses can be minimized. Obviously the first step is what and how these risks are addressed. Based on the findings in the field of risk control is done in the first three stages, before financing, both when financing and the third is after financing.
\end{abstract}

Keyword : financing, mudaraba,risk and return 


\section{LATAR BELAKANG}

Dalam dunia bisnis sangat lekat dan dekat dengan kondisi ketidakpastian. Ketidakpastian tersebut akan berdampak pada keuntungan atau kerugian atau sering disebut dengan risk and return (risiko dan hasil). Risiko dan hasil adalah berkorelasi positif, semakin besar risiko bisnis, maka peluang untuk mendapatkan laba atau pendapatan (return) juga besar, sebaliknya jika risiko bisnis kecil, maka laba atau pendapatan (return) yang akan diperoleh juga akan kecil.

Risk and return (risiko dan hasil) juga tidak lepas pada lembaga keuangan khususnya koperasi. Pengertian koperasi menurut Undang-Undang No. 25 Tahun 1992 tentang Perkoperasian, adalah badan usahayang beranggotakan orang-seorang atau badan hukum Koperasi dengan melandaskan kegiatannya berdasarkan prinsip Koperasi sekaligus sebagai gerakan ekonomi rakyat yang berdasar atas asas kekeluargaan. Koperasi sebagai lembaga keuangan tersebut, juga tidak dapat mengelak atas kemungkinan terjadinya risiko. Dengan adanya risiko memaksa koperasi untuk dapat mengidentifikasi setiap risiko yang sedang dan akan dihadapi dengan merujuk risiko yang pernah dialami. Dengan mengenali risiko lebih awal diharapkan koperasi dapat meminimalisir risiko yang ada, sehingga return yang telah ditetapkan dapat tercapai.

Menurut Darmawi (2006), risiko dihubungkan dengan kemungkinan terjadinya akibat buruk (kerugian) yang tidak diinginkan atau tidak terduga. Senada dengan hal itu
Djojosoedarso (1999) menyatakan, bahwa risiko mempunyai karakteristik :

a. Merupakan ketidakpastian atas terjadinya suatu peristiwa,

b. Merupakan ketidakpastian yang bila terjadi akan menimbulkan kerugian.

Ada beberapa jenis risiko yang berhubungan dengan dunia bisnis utamanya yang berkaitan dengan bisnis keuangan (financing) diantaranya adalah risiko kredit (credit risk), risiko likuiditas (liquidity risk) dan risiko tingkat bunga (interest rate). Di samping itu ada resiko nilai tukar valuta asing (foreign exchange rate risk) dan risiko operasional (operational risk). Dari berbagai jenis resiko di atas, risiko dapat dibedakan menjadi dua kelompok besar yaitu (1) resiko yang sistematis (systematic risk) adalah risiko yang diakibatkan oleh adanya kondisi atau situasi tertentu yang bersifat makro, seperti perubahan situasi politik, perubahan kebijakan ekonomi pemerintah, perubahan situasi pasar, situasi krisis atau resesi. (2) Risiko yang tidak sistematis (unsystematic risk) adalah risiko yang unik, yang melekat pada perusahaan atau bisnis tertentu saja. Pada lembaga keuangan, dalam hal ini adalah koperasi baik yang menggunakan prinsip syariah maupun konvensional, maka lembaga keuangan yang didirikan berbasis kekeluargaan inipun juga berpotensi menghadapi risiko-risiko tersebut kecuali risiko tingkat bunga, karena Lembaga Keuangan Islam (koperasi syariah) tidak akan akan berurusan dengan bunga (Arifin, 2002).

Pada koperasi syariah yang berkaitan dengan pembiayaan adalah bagi hasil yang berbasis profit and loss sharing adalah 
pembiayaan musyarakah dan pembiayaan mudharabah, namun pada pembiayaan musyarakah masih terdapat kesempatan untuk mengantisipasi terjadinya risiko karena pihak pemilik dana (shahibul maal) masih dapat berpartisipasi dalam manajemen usaha. Sedangkan pada pembiayaan mudharabah pihak pemilik dana (shahibul maal) tidak ikut serta dalam manajemen usaha, sehingga internal usaha tidak dapat diketahui secara detail.

Dengan adanya kemungkinan terjadinya risiko dan untuk meminimalisir terjadi risiko yang mungkin akan terjadi pada pembiayaan mudharabah di koperasi syariah, maka perlu diteliti mengenai risiko apa saja yang ada pada pembiayaan tersebut tentang bagaimana cara penanganan risiko secara cepat dan tepat. Hal inilah yang menjadi dorongan untuk meneliti lebih dalam yang berkaitan dengan "Analisis Manajemen Risiko Pembiayaan Mudharabah Di Koperasi Syariah Boyolali (Studi Atas BMT Salaam dan KJKS Surya Madani). Sedangkan dipilihnya kedua obyek tersebut adalah sebanding karena kedua obyek penelitian tersebut mempunyai jaringan nasabah yang cukup merata dilapisan masyarakat.

\section{Rumusan Masalah}

Skim pembiayaan mudharabah adalah pembiayaan yang sangat didasarkan pada kepercayaan baik dalam kepercayaan terhadap personal maupun kepercayaan terkait dengan manajerial. Berdasar atas permasalahan di atas maka, dalam penelitian ini akan fokus pada 2 (dua) masalah pokok yaitu :

1. Risiko apa sajakah yang terdapat dalam pembiayaan mudharabah di koperasi syariah di Boyolali (BMT Salaam dan KJKS Surya Madani) ?

2. Dalam mengantisipasi risiko yang dapat timbul dari pembiayaanmudharabah, bagaimana strategi manajemen risiko pembiayaan mudharabah di koperasi syariah di Boyolali (BMT Salaam dan KJKS Surya Madani)?. Apakah dari kedua koperasi tersebut memiliki cara yang berbeda dalam mengelola risiko dalam pembiayaan mudharabah?

\section{Tujuan Penelitian}

1. Untuk mengetahui risiko apa sajakah yang terdapat dalam pembiayaan mudharabah di koperasi syariah di Boyolali (BMT Salaam dan KJKS Surya Madani)

2. Untuk mengetahui langkah-langkah antisipasi atas risiko yang dapat timbul dari pembiayaan mudharabah, serta bagaimana strategi manajemen risiko pembiayaan mudharabah di koperasi syariah di Boyolali (BMT Salaam dan KJKS Surya Madani) ? Apakah dari kedua koperasi tersebut memiliki cara yang berbeda dalam mengelola risiko dalam pembiayaan mudharabah?

\section{TINJAUAN PUSTAKA}

Ada beberapa penelitian yang membahas tentang manajemen risiko pembiayaan mudharabah, salah satunya adalah Nasih et.al. (2008) Manajemen Risiko 
Pembiayaan Mudharabahpada Perbankan Syariah. Dalam penelitian tersebut dipaparkan bahwa pada laporan keuangan baik pada BMI, BSM, maupun BNIS, aset yang dimiliki melalui pembiayaan mudharabah memiliki jumlah cukup rendah dibandingkan dengan pembiayaan murabahah, hal ini disebabkan karena penyaluran dana melalui pembiayaan mudharabah memiliki risiko yang cukup besar, yaitu pada risiko kerugian, khususnya pada penghasilan yang akan diterima oleh bank.

Selanjutnya risiko kerugian yang ditanggung oleh bank sebagai shahibul maal adalah karena tingginya jumlah pembiayaan bermasalah mulai dari kurang lancar bahkan macet. Penyebabnya adalah hilangnya kemampuan untuk membayar angsuran serta bagi hasil kepada bank dikarenakan nasabah melakukan kelalaian. Kelalaian tersebut yaitu terjadinya side streaming, memanipulasi data (asymmetric information), sehingga menyebabkan kesalahan dalam menganalisa kemampuan nasabah. Dari permasalahan tersebut upaya yang dilakukan bank dalam penyelamatan terhadap pembiayaan bermasalah, yaitu dengan cara rescheduling, reconditioning, restructuring, ini dilakukan jika nasabah dianggap masih memiliki niat untuk membayar. Jika tidak, akan dilakukan eksekusi jaminan. Di sisi lain kerugian yang muncul diakibatkan murni karena risiko bisnis bukan kelalaian nasabah (force majeure), baik pada BMI, BSM, ataupun BNIS, tidak secara langsung menanggung seluruh kerugian usaha yang dibiayai. Bank sengaja memberi pengamanan berlapis pada dana masyarakat yang digunakan sebagai dana pembiayaan dengan melakukan kerjasama dengan pihak asuransi untuk mengcover kerugian tersebut
Di samping itu Sumar'in juga melakukan penelitian tentang Strategi Manajemen Risiko Pada Pembiayaan Murabahah (Studi Kasus BTN SyariahYogyakarta Pada Produk KPR Periode 2009), bahwa terdapat risiko potensial yang dihadapi oleh Manajemen BTN Syariah dalam pembiayaan KPR dengan akad murabahah yaitu meliputi risiko pembiayaan, risiko pasar, risiko operasional dan risiko hukum. Adapun pola penerapan manajemen risiko dalam bentuk pengelolaan risiko itu sendiri dibagi dua pola yaitu pengelolaan risiko berdasarkan risiko pembiayaan dengan melakukan seleksi awal, melakukan analisis dan pengukuran risiko terhadap nasabah dan agunan, melakukan monitoring. Risiko pasar, dikelola dengan menerapkan manajemen harga dan memperketat penilaian agunan. Risiko operasional dikelola dengan penerapan prudential banking practice dan penerapan good corporate governance (GCG). Adapun risiko hukum dikelola dengan strategi penyusunan klausul dengan strategi penyusunan klausul kontrak dengan teliti, memastikan keabsahan berkas kontrak dan pengawasan dari Badan Pengawas Syariah (DPS).

Pengelolaan risiko model kedua dilakukan dengan berdasarkan tahapan pembiayaan yang meliputi manajemen risiko sebelum akad, manajemen risiko pada saat akad dan manajemen risiko setelah akad. Manajemen risiko dalam bentuk pengalihan risiko (risk transfer) adalah dengan mengasuransikan nasabah dan agunan dalam bentuk asuransi jiwa dan kebakaran pada pihak asuransi syariah. Sedangkan model 
penerapan manajemen risiko dalam bentuk penghindaran risiko (risk avoidence) dilakukan dengan memperketat proses seleksi pembiayaan, penerapan prinsip prudent dan memperbesar pembiayaan dengan akad murabahah.

Di sisi lain Trianti (2014) meneliti Manajemen Risiko Pembiayaan Mudharabah (Studi Kasus Bank Muamalat Indonesia Cabang Malang),ditemukan dalam penelitiannya bahwa manajemen risiko dalam pembiayaan mudharabah di Bank Muamalat Indonesia Cabang Malang adalah suatu upaya untuk meminimalisir risiko yang terjadi, baik pada tahapan pra akad dan pasca akad. Mitigasi pra akad dilakukan dengan mematuhi Standard Operational Procedure yang ditetapkan internal bank, melakukan seleksi calon mudharib, dan melakukan analisa kelayakan usaha calon mudharib. Sedangkan mitigasi risiko pasca akad dilakukan dengan monitoring secara berkala kondisi usaha mudharib dan melakukan pembinaan usaha mudharib.

\section{Mudharabah Menurut Hukum Islam}

Salah satu karakteristik khas lembaga keuangan syariah adalah adanya sistem bagi hasil. di mana sistem bagi hasil ini sangat dekat dengan sistem mudharabah. Secara teknis, mudharabahadalah akad kerjasama usaha antara dua pihak di mana pihak pertama (shahib al-māl) menyediakan seluruh (100\%) modal, sedangkan pihak lainnya menjadi pengelola (mudharib). Keuntungan usaha secara mudharabah dibagi menurut kesepakatan yang dituangkan dalam kontrak, sedangkan apabila rugi ditanggung oleh pemillik modal, selama kerugian tersebut bukan akibat kelalaian pengelola (Antonio, 2000).

1. Pengertian mudārabah.

Secara etimologi kata mudharabah berasal dari kata dharb. Dalam bahasa Arab, kata ini termasuk kata yang mempunyai banyak arti, diantaranya adalah : memukul, berdetak, mengalir, berenang, bergabung, menghindar, berubah, mencampur, berjalandan lain sebagainya. Perubahanperubahan yang terjadi dalam kata-kata tersebut tampak tergantung pada kata yang mengikutinya dan konteks yang membentuknya. Namun dibalik keluwesan kata ini dapat mempresentasikan keragaman makna yang ditimbulkannya yaitu bergeraknya sesuatu kepada sesuatu yang lain.

Dalam fiqih muamalah, definisi terminologi mudharabah diungkap secara bermacam-macam oleh beberapa ulama madzhab. Diantaranya menurut madzhab Hanafi mendefinisikan mudharabahadalah suatu perjanjian untuk berkongsi di dalam keuntungan dengan modal dari salah satu pihak dan kerja usaha dari pihak lain. Sementara madzhab Maliki menamai mudharabah adalah penyerahan uang di muka oleh pemilik modal dalam jumlah uang yang ditentukan kepada seorang yang akan menjalankan usaha dengan uang itu dengan imbalan sebagian dari keuntungannya. Madzhab Syafi'i mendefinisikan mudharabaha dalah bahwa pemilik modal menyerahkan sejumlah uang kepada pengusaha untuk dijalankan dalam suatu 
usaha dagang dengan keuntungan menjadi milik bersama antara keduanya (Muhammad, 2005).

Menurut Saeed (2004), pengertian mudharabah adalah kontrak antara dua pihak dimana satu pihak yang disebut rab al maal (investor) mempercayakan uang kepada pihak ke dua, yang disebut mudārib untuk tujuan menjalankan usaha dagang. Mudārib menyumbangkan tenaga dan waktunya dan mengelola kongsi mereka sesuai dengan syarat-syarat kontrak. Salah satu ciri utama dari kontrak ini adalah bahwa keuntungan, jika ada, akan dibagi antara investor dan mudārib berdasarkan proporsi yang telah disepakati sebelumnya. Kerugian, jika ada, akan ditanggung sendiri oleh investor.

2. Landasan Syariah Mudārabah

Secara umum landasan dasar syariah mudharabahlebih mencerminkan anjuran untuk melakukan usaha. Hal ini tampak dari ayat-ayat dan hadits berikut ini : Q.S. Al Muzzamil : 20, Al-Baqarah : 198, An-Nisa': 29

Dari Shalih bin Suhaib ra. Bahwa Rasulullah SAW bersabda: "Tiga hal yang di dalamnya terdapat keberkatan : jual beli secara tangguh, muqaradhah (mudārabah) dan mencampur gandum dengan tepung untuk keperluan rumah bukan untuk dijual." (H.R. Ibnu Majah).

3. Rukun dan Syarat Akad Mudārabah.

Menurut Jumhur Ulama rukun akad mudharabahadalah (Affandi, 2004) :

1) A'qidain (dua orang yang berakad) yaitu (pemilik modal/ investor/sāhib al-māl dan pengelola modal/mudārib).
2) Al maal (modal) sejumlah dana yang dikelola.

3) $\mathrm{Al}$ ribh (keuntungan), laba yang didapatkan untuk dibagi bersama sesuai kesepakatan.

4) Al a'mal (usaha) dari mudārib.

5) Shighat (ucapan serah terima).

Syarat-syarat mudharabah adalah yang terkait dengan syarat orang yang melakukan akad (aqidain), terkait dengan modal dan terkait dengan keuntungan.

a. Syarat yang terkait dengan orang yang melakukan akad (aqidain) yaitu:

1) Cakap bertindak hukum dan cakap diangkat sebagai akid (orang yang berakad).

2) Pemilik dana (sāhib al-māl) tidak boleh mengikat dan melakukan intervensi kepada pengelola (mudārib) dalam mengelola dananya.

b. Syarat yang terkait dengan modal yaitu :

1) Modal harus berupa uang dan Ulama tidak memperbolehkan modal dalam bentuk barang.

2) Besarnya modal ditentukan dengan jelas.

3) Modal bukan merupakan pinjaman (hutang). Modal yang merupakan pinjaman pada hakikatnya bukan merupakan harta dari shahib al-maal.

4) Modal diserahkan langsung kepada pengelola secara tunai.

5) Modal digunakan sesuai dengan syarat-syarat akad yang disepakati. 
6) Pengembalian modal dapat dilakukan bersamaan dengan waktu penyerahan bagi hasil atau pada saat berakhirnya masa mudharabah.

7) Pada prinsipnya dalam mudharabah tidak diperkenankan mengenakan jaminan. Namun agar pengelola dana tidak melakukan penyimpangan pemilik dana dapat meminta jaminan dari mudharib. Jaminan dapat dicairkan jika mudārib melakukan pelanggaran terhadap hal-hal yang telah disepakati.

4. Jenis-Jenis mudharabah (Antonio, 2000) :

a. Mudharabah Muthlaqah

Yang dimaksud dengan transaksi mudharabah muthlaqah (unrestricted mudharabah) adalah bentuk kerjasama antara shahib al-maal dan mudharib yang cakupannya sangat luas dan tidak dibatasi oleh spesifikasi jenis usaha, waktu dan daerah bisnis.

b. Mudharabah Muqayyadah

Mudharabah muqayyadah atau disebut restricted mudharabah/ specified mudharabah adalah kebalikan dari mudharabah muthlaqah. Si mudārib dibatasi dengan dengan batasan jenis usaha, waktu atau tempat usaha. Adanya pembatasan ini seringkali mencerminkan kecenderungan umum si sāhib al-māl dalam memasuki jenis dunia usaha.

Teori Pembiayaan Mudharabah di Lembaga Keuangan Syariah
Pembiayaan, secara luas adalah pembelanjaan (financing) yaitu pendanaan yang dikeluarkan untuk mendukung investasi yang telah direncanakan baik di kalangan sendiri maupun dijalankan oleh yang lain (Muhammad, 2005). Menurut sifatnya pembiayaan dibagi menjadi dua yaitu pembiayaan yang bersifat produktif dan pembiayaan yang bersifat konsumtif (Antonio, 2000). Pembiayaan produktif adalah pembiayaan yang digunakan untuk memenuhi kebutuhan usaha atau produksi agar usaha tesebut meningkat baik produksi perdagangan maupun investasi. Sedangkan pembiayaan konsumtif adalah pembiayaan yang dipergunakan untuk kebutuhan konsumsi yang habis pakai. Pembiayaan yang sering diterapkan dalam koperasi syariah adalah pembiayaan yang bersifat produktif dengan memakai akad mudharabah atau yang lebih dikenal dengan sistem bagi hasil (profit and loss sharing/PLS).

\section{Manajemen Risiko Pembiayaan Mudharabah}

Sedangkan manajemen risiko adalah serangkaian metodologi dan prosedur yangdigunakan untuk mengidentifikasi, mengukur, memantau, dan mengendalikan risiko yang timbul dari seluruh kegiatan usaha.

Manajemen risiko (risk management) berbeda dengan pengawasan atau pengendalian risiko (risk controll). Manajemen risiko adalah pengambilan keputusan yang rasional dalam keseluruhan proses penanganan risiko, termasuk risk assessment, sebagaimana tindakan untuk 
membangun dan menerapkan pilihan-pilihan risiko. Sedangkan pengawasan atau pengendalian risiko adalah tindakan yang dirancang untuk mengurangi risiko, seperti perubahan prosedur, perbaikan fasilitas, supervisi ekstra dan sebagainya (Muhammad, 2005).

Bisnis lembaga keuangan termasuk koperasi akan berhadapan dengan berbagai jenis risiko kredit, di antaranya adalah :

1. Risiko modal (capital risk)

Risiko modal adalah merefleksikan tingkat leverage yang dipakai. Salah satu fungsi modal adalah melindungi para penyimpan dana terhadap kerugian yang tejadi. Jumlah modal yang dibutuhkan untuk melindungi para penyimpan dana berhubungan dengan kualitas dan risiko dari aset. Koperasi yang menggunakan sebagian besar dananya untuk mendanai aset yang berisiko perlu memiliki modal penyangga yang besar untuk sandaran bila kinerja aset-aset itu tidak baik. Tingkat modal juga penting untuk menyangga risiko liquiditas.

2. Risiko Pembiayaan

Risiko pembiayaan muncul jika tidak dapat memperoleh kembali cicilan pokok dan/atau bunga dari pinjaman yang diberikannya atau investasi yang sedang dilakukannya.

3. Risiko Likuiditas

a. Risiko Likuiditas

Likuiditas adalah kemampuan untuk memenuhi kebutuhan dana (cash flow) dengan segera dan dengan biaya yang sesuai. Risiko likuiditas muncul manakala koperasi mengalami ketidakmampuan untuk memenuhi kebutuhan dana (cash flow) dengan segera dan dengan biaya yang sesuai, baik untuk memenuhi kebutuhan sehari-hari maupun untuk memenuhi kebutuhan dana yang mendesak.

b. Risiko Operasional

Menurut definisi Bassle Committee, risiko operasional adalah risiko akibat dari kurangnya (deficiencies) sistem informasi atau sistem pengawasan internal yang akan menghasilkan kerugian yang tidak diharapkan. Risiko ini berkaitan dengan kesalahan manusiawi (human error), kegagalan sistem, dan ketidakcukupan prosedur dan kontrol.

\section{METODE PENELITIAN}

Pembahasan metodologi penelitian adalah membahas tentang cara-cara ilmiah dalam mendapatkan/menemukan ilmu baru secara benar (Muhammad, 2003), dengan demikian pada bagian ini memaparkan metode penelitian yang akan digunakan dalam penelitian ini.

\section{Jenis dan Metode Penelitian}

Jenis penelitian adalah penelitian kualitatif dan termasuk penelitian lapangan (field research) yaitu suatu penelitian yang dilaksanakan secara intensif, terperinci dan mendalam terhadap objek dilapangan untuk memperoleh informasi dan data sesuai permasalahan penelitian (Muhammad, 2003), yang kemudian membutuhkan analisis yang komprehensif dan menyeluruh. Di samping 
itu dalam penelitian ini menggunakan analisis descriptive, yaitu untuk menganalisis data yang telah dikumpulkan atau diperoleh di lapangan dengan teknik wawancara, observasi dan dokumentasi, yang kemudian dipaparkan dengan penelusuran yang lebih mendalam, untuk menemukan kelebihan masing-masing koperasi.

\section{Populasi dan Sampel Penelitian}

Populasi penelitian ini adalah terdapat dua koperasi syariah yang terdapat di Kabupaten Boyolali yaitu BMT Salaam dan KJKS Surya Madani, sedangkan sampel penelitian ini adalah pengelola BMT Salaam dan KJKS Surya Madani, sehingga data yang diperoleh lebih valid dan akurat.

Pengambilan sampel dilakukan dengan cara purposive sampling yaitu sampel yang dipilih dengan cermat hingga relevan dengan mengambil orang-orang yang terpilih betul oleh peneliti menurut ciri-ciri yang spesifik dangan desain kualitatif (Nasution, 2006). Dengan jumlah sampel sebanyak dua orang yang berwenang dibidang pembiayaan di koperasi syariah di Kabupaten Boyolali.

\section{Sumber Data dan Teknik Pengumpulan Data}

Penelitian ini merupakan studi kasus (case studies) maka data primer dapat diperoleh dengan teknik/metode observasi, wawancara, dan dokumentasi (Sugiono, 2003)

JURNAL ILMIAH EKONOMI ISLAM VOL. 01 NO. 03, NOVEMBER 2016 a. Observasi yaitu mengadakan pengamatan langsung dan pencatatan secara sistematis terhadap fokus permasalahan yang diteliti secara sistematis (Sutrisno, 1984), dalam hal ini mengobservasi langsung di lapangan.

b. Wawancara Mendalam (In Depth Interview).

Dalam penelitian kualitatif, metode pengumpulan data melalui wawancara mendalam merupakan metode utama, dengan alasan: pertama, dengan wawancara peneliti dapat menggali tidak saja apa yang kasat mata (diketahui atau dialami oleh subyek penelitian) namun juga apa yang jauh tersembunyi jauh di dalam diri subyek penelitian (explicit knowledge and tacit knowledge). Kedua, apa yang ditanyakan oleh informan bisa mencakup hal-hal yang bersifat lintas waktu yang berkaitan dengan masa lampau, masa sekarang dan masa yang akan datang (Subadi, 2011). Sedangkan yang dimaksud dengan wawancara mendalam sendiri adalah metode pengumpulan data yang diperoleh melalui percakapan atau wawancara secara mendalam yang dilakukan oleh dua pihak yaitu pewawancara (interviewer) yang mengajukan dan yang diwawancarai (interviewee) yang memberikan jawaban atas pertanyaan itu. Penentuan responden sebagai informan dipilih melalui penelusuran orang-orang yang berkompeten dan dapat mewakili serta representatif dalam penggalian informasi yang dibutuhkan. Dalam hal ini interview dilakukan 
dengan pihak yang menangani pembiayaan mudārabah, prosedur pembiayaan serta manajemen risiko yang diterapkan untuk meminimalisir kerugian, termasuk dengan beberapa karyawan operasional yang secara langsung terkait dengan pembiayaan tersebut. Teknik wawancara ini dilakukan dalam bentuk wawancara yang tidak terstruktur yaitu berupa dialog atau tanya jawab yang dilakukan dalam bentuk bebas (inguided interview). Hal ini dilakukan agar yang diwawancari tidak kaku dalam menjawab pertanyaan (relax) sehingga data-data dapat diperoleh secara maksimal mungkin, akan tetapi tidak menyimpang dari standar pertanyaan yang dibutuhkan dan lebih diarahkan pada hal-hal yang menjadi objek permasalahan.

c. Dokumentasi, (Arkunto, 1998) teknik pengumpulan data ini juga dikenal dengan penelitian dokumentasi (documentation research) yaitu mengumpulkan data-data yang terkait dengan fokus penelitian yang berasal dari sumber utamanya (obyek penelitian) seperti dokumen-dokumen atau arsip-arsip baik itu sejarah, visi dan misi di BMT Salaam dan KJKS Surya Madani.

\section{Instrumen Penelitian}

Adapun pertanyaan utama dalam penelitian ini dirumuskan sebagai berikut:
1. Risiko apa sajakah yang ada pada pembiayaan mudharabah?

2. Bagaimana carashahib al-maal (BMT Salaam dan KJKS Surya Madani) dalam rangka memperkecil risiko pada pembiayaan mudharabah?

3. Apakah dari kedua bank tersebut memiliki cara yang berbeda dalam mengelola risiko dalam pembiayaan mudharabah? Dari tiga pertanyaan utama tersebut kemudian dikembangkan sebagai pedoman wawancara dalam penggalian data.

\section{Teknik Analisis Data}

Analisis data adalah proses mengorganisasikan dan mengurutkan data kedalam pola kategori dan satuan uraian dasar sehingga dapat ditemukan tema dan dapat dirumuskan hipotesis kerja yang disajikan oleh data (Moleong, 2000). Teknik analisis data dalam penelitian ini dilakukan sejak pengumpulan data berlangsung dilapangan dan setelah pengumpulan data berlangsung, Aktivitas analisis data dilakukan secara interaktif dan terus menerus sampai tuntas, sehingga datanya berkesinambungan (Miles dan Hubermas, 2008).

Data yang telah dikumpulkan kemudian direduksi, dimana dipola kedalam beberapa kategori untuk memilih dan memilah antara yang penting dan yang tidak penting. Dengan demikian dapat teruji validasi dan akurasi data yang diperoleh. Untuk menganalisis manajemen risiko pada pembiayaan mudharabah dalam mengantisipasi dan 
mengatasi risiko yang mungkin timbul, maka dalam penelitian ini menggunakan analisis data secara deskriptif kualitatif. Analisis data ini menggunakan pendekatan proses alur. Pertama, analisis data yang muncul berwujud kata-kata, data ini dikumpulkan dari dokumentasi. Kedua, analisis ini terdiri dari tiga alur kegiatan yaitu reduksi data (data-data dari lapangan), penyajian data dan penarikan kesimpulan (Miles dan Hubermas, 2008). Dari kesimpulan yang ditarik akan dilakukan pemaparan dan perbandingan (persamaan dan perbedaan dalam manajemen risiko pembiayaan mudharabah) dari kedua koperasi syariah tersebut (BMT Salaam dan KJKS Surya Madani).

\section{PEMBAHASAN}

\section{Analisis Risiko Yang Muncul Pada Pembiayaan Mudārabah di Koperasi Syariah di Boyolali}

\section{Sebelum Akad Pembiayaan}

Berdasarkan data yang diperoleh di lapangan bahwa koperasi syariah di Boyolali (KJKS BMT Salaam dan KJKS Surya Madani) dalam memberikan pembiayaan mudārabah memiliki beberapa syarat-syarat dan prosedur yang harus dipenuhi oleh nasabah (mudārib). Ketentuan dan prosedur ini adalah sebagai proses verifikasi pertama atas data dari mudārib dan tujuan penggunaan pembiayaan yang diajukan. Dari verifikasi awal bank selaku sāhib al-māl akan mempelajari dan kemudian akan observasi, wawancara mendalam, dan

memberikan keputusan atas pengajuan pembiayaan tersebut.

Penyaluran pembiayaan mudārabah di KJKS BMT Salaam dan KJKS Surya Madani diberikan kepada nasabah yang mempunyai usaha yang jelas atau cash flow yang jelas pula. Hal ini senada dengan hasil wawancara Maryoko Budi Santoso selaku Manajer KJKS BMT Salaam ${ }^{1}$ dan Abdani Manajer KJKS Surya Madani ${ }^{2}$ yang rata-rata adalah untuk pembiayaan perorangan atau individu.

KJKS BMT Salaam lebih banyak bergerak pada para pedagang pasar atau nasabah yang sudah mempunyai usaha selama minimal dua tahun. Hal ini dimaksudkan bahwa nasabah mempunyai basis usaha dengan pelanggan yang cukup kuat dalam menopang kelangsungan usahanya. Sementara KJKS BMT Surya Madani selain perorangan juga merambah nasabah institusional namun sebagian masih belum berbadan hukum.

Kedua koperasi syariah tersebut dalam menyalurkan pembiayaan mudharabah terlebih dahulu menjelaskan dalam menentukan nisbah bagi hasil yang nantinya akan disepakati. Selain itu persyaratan administrasi juga dijelaskan supaya pembiayaan yang telah disalurkan tidak mengalami masalah.

Secara umum mekanisme yang ditetapkan oleh kedua koperasi syariah tersebut, bahwa nasabah harus memenuhi syarat-syarat administratif sebagai proses awal dalam pengajuan pembiayaan, antara lain :

1. Nasabah atau mudārib mengisi JURNAL ILMIAH EKONOMI ISLAM VOL. 01 NO. 03, NOVEMBER 2016 
formulir permohonan pembiayaan yang tersedia.

2. Menjelaskan gambaran umum usaha, rencana prospek usaha, rincian penggunaan dana, jumlah dana yang dibutuhkan dan jangka waktu yang pembiayaan.

3. Laporan keuangan/cash flow secara jelas walaupun sederhana, untuk mengetahui kondisi keuangan dan potensi laba yang dapat diperoleh.

4. Jaminan sebagai bahan pertimbangan untuk memberikan pembiayaan.

Koperasi syariah sebagai lembaga keuangan yang berbasis syar'i, yang dikelola berdasarkan sikap amanah /dengan keterbukaan dan fathonah (profesional), maka supaya nilai-nilai yang Islami tersebut tetap terjaga, harus selektif dalam menyalurkan pembiayaan yang tidak ada unsur maisir, gharar dan riba (maghrib). Dengan demikian kriteria dengan pembiayaan mudārabah adalah sebagai berikut:

1. Usaha yang dibiaya memiliki risiko yang terukur dalam arti tidak berpeluang besar yang dapat merugikan bank selaku pemilik dana.

2. Laporan keuangan yang transparan supaya usaha dijalankan saling menguntungkan dan tidak merugikan di pihak lain.

3. Memberikan keuntungan yang jelas.

4. Jaminan atas dana yang dipinjam dari koperasi syariah.

5. Jangka waktu yang terukur dan terencana.

6. Jumlah pembiayaan yang disesuaikan dengan kebutuhan dan kemampuan.

7. Prospek proyek yang dibiayai memiliki pangsa pasar yang jelas.

Berdasarkan pengalaman di lapangan, risiko yang timbul sebelum akad pembiayaan adalah sebagai berikut :

1. Adanya dokumen persyaratan pembiayaan yang tidak valid (aspal/asli namun palsu), sehingga apabila tidak cermat akan bermasalah di kemudian hari.

2. Track record BI checking yang tidak sesuai standar (hal ini hanya dilakukan oleh KJKS BMT Surya Madani yang mengajukan pembiayaan di atas Rp.50.000.000,- /lima puluh juta rupiah).

3. Mengverifikasi jaminan untuk menjamin keasliannya.

4. Survei tempat tinggal dan tempat usaha supaya lebih yakin mengenai kondisi riil dari nasabah.

\section{Ketika Pembiayaan}

Aktifitas bisnis selalu berhadapan dengan kondisi ketidakpastian. Ketidakpastian yang ada akan menimbulkan apakah bisnis yang dijalankan akan untung atau rugi, dengan kata lain risk and return (risiko dan pendapatan) adalah seperti sekeping mata uang yang tidak dapat dipisahkan. Semakin besar risiko bisnis, maka peluang untuk mendapatkan laba atau pendapatan (return) juga besar, sebaliknya jika risiko bisnis kecil, return juga kecil.

Termasuk dalam ketika proses pembiayaan adalah mengverifikasi akhir 
dari syarat-syarat jaminan sebagai syarat administrasi perlu dipertegas dan diperjelas, supaya di kemudian hari tidak menimbulkan permasalahan. Persyaratan administrasi penting untuk dicermati karena sebagai syarat keabsahan akad pembiayaan.

\section{Sesudah Pembiayaan}

Realisasi atau pencairan pembiayaan akan benar-benar diberikan manakala nasabah memang layak untuk diberikan pembiayaan tersebut. Proses setelah pencairan pembiayaan adalah yang sangat urgen, karena setelah pencairan inilah akan kelihatan keasliannya teutama karakter dan kemampuan dalam membayarnya (ability to pay). Maka dari itu setelah pencairan koperasi syariah di Boyolali akan terus memantau usaha nasabah supaya jangan sampai collapse.

Hal itu wajar karena pembiayaan mudārabah adalah pembiayaan yang paling berisiko mengingat untung-ruginya usaha yang menjalankan adalah nasabah (mudārib). Sementara jika terjadi kerugian, koperasi (sāhib al-māl) akan menanggung risiko atau kerugiannya, selama kerugian tersebut bukan disebabkan karena kelalaian.

\section{KESIMPULAN DAN SARAN}

Berdasarkan hasil analisis data-data dan informasi-informasi dapat ditarik kesimpulan sebagai berikut :

\section{Kesimpulan}

Bahwa KJKS BMT Salaam dan KJKS Surya Madani dalam menyalurkan pembiayaan mudārabah memiliki sistem, prosedur dan manajemen tersendiri untuk memperkecil risiko kerugian mulai awal akad atau sebelum akad terjadi, dalam proses akad dan setelah akad terjadi sampai pada realisasi dana. Pada awal atau sebelum akad pembiayaan KJKS BMT Salaam dan KJKS Surya Madani di Boyolali memastikan bahwa data-data administratif telah memenuhi ketentuan yang berlaku di kedua koperasi tersebut.

Di samping itu kedua koperasi tersebut juga memiliki perbedaan dalam kebijakan sebelum penyaluran pembiayaan seperti menggunakan BI checking atau tidak.

\section{Saran-saran}

Adapun saran-saran yang dapat penulis sampaikan adalah :

a. Perlunya penelitian dengan topik yang sama dengan skim pembiayaan yang berbeda seperti ; musyarakah maupun murabahah atau jenis pembiayaan yang lainnya.

b. Keterbatasan dalam memperoleh datadata di lapangan karena harus mematuhi aturan yang dikeluarkan oleh bank syariah itu sendiri maupun aturan dari Bank Indonesia, sehingga penelitian ini kurang mendalam. 


\section{DAFTAR PUSTAKA}

Afandi, Yazid, Fiqh Muamalah, Cet. I,Yogyakarta : Logung Pustaka, 2009.

Ali, Masyhud, Manajemen Risiko: Strategi Perbankan dan Dunia Usaha Menghadapi Tantangan Globalisasi Bisnis, Jakarta: Raja Grafindo Press, 2006.

Antonio, Muhammad Syafi'i, BANK SYARIAH : Suatu Pengenalan Umum, Edisi Khusus, Cet. I, Jakarta : Tazkia Institute, 2000.

Antonio, Syafii, Bank Syariah : Dari Teori Ke Praktek,Jakarta:Gema Insani, 2001.

Arifin, Zainul, Dasar-Dasar Manajemen Bank Syariah, Jakarta: Alfabeta, 2002.

Arikunto, Suharsimi, Prosedur Penelitian : Suatu Pendekatan Praktek, Jakarta : Rineka Cipta, 1998.

Darmawi, H. 2006. Manajemen Risiko.Cetakan kesepuluh. Jakarta : Bumi Aksara.

Darmawi, Herman, Manajemen Risiko, Edisi I, Cet. XI, Jakarta : Bumi Aksara, 2008.

Djojosoedarso, S. $1999 . \quad$ PrinsipPrinsipManajemen Risiko dan Ansuransi. Jakarta :Salemba Empat.

Greuning, Heni Van dan Bratanovic, Sonja Brajovic, Analisis Risiko Perbankan, Terj. M. Ramdhan Adhi, Edisi III,Jakarta : Salemba Empat, 2011

Hadi, Sutrisno, Metodologi Research 2 (Yogyakarta: Yayasan Penerbitan Fakultas Psikologi UGM,1984

Harahap, Sofyan S., Bunga Rampai: Ekonomi, Bisnis \& Manajemen Islami, Cet. I, Yogyakarta: BPFE, 2004.
Karim, Adiwarman, Bank Islam: Analisis Fiqih dan Keuangan, Edisi III, Jakarta:PT.Raja Grafindo Persada, 2007.

Kuncoro, Mudrajat, Metode Riset Untuk Bisnis Dan Ekonomi; Bagaimana Meneliti Dan Menulis Tesis, Jakarta: Erlangga, 2003.

Miles dan Habermas, Memahami Penelitian Kualitatif, Bandung: Alfabeta, 2008.

Moleong, Laxy J., Metodologi Penelitian Kualitatif, Bandung: Remaja Rosdokarya, 2000.

Muhammad, Konstruksi MudharabahDalam Bisnis Syariah, Cet. I Yogyakarta : BPFE - Yogyakarta, 2005.

Muhammad, Manajemen Bank Syariah ,Yogyakarta : UPP AMP YKPN, 2005.

Muhammad, Manajemen Pembiayaan Bank Syariah, Yogyakarta: UPP AMP YKPN, 2005.

Muhammad, Manajemen Pembiayaan Mudharabahdi Bank Syariah, Edisi I, Jakarta: PT. Rajawali Grafindo, 2008.

Nasih, Mohammad, et. al, 2013, Manajemen Risiko Pembiayaan Mudharabah pada Perbankan Syariah, Media Trend Vol. 8 No. 2. Universitas Airlangga Surabaya.

Nasution, Metode Research (Penelitian Ilmiah), Cet. VIII, Jakarta: Bumi Aksara, 2006.

Saeed, Abdullah, Menyoal Bank Syariah, Terj. Arif Maftuhin, Cet. I Jakarta:Paramadina,2004.

Salim, Abbas, Asuransi dan Manajemen Risiko, Jakarta : PT Raja Grafindo Persada, 2007. 
Sholahuddin, Muhammad, Lembaga Ekonomi dan Keuangan Islam, Cet. I, Surakarta :MuhammadiyahUniversity Press UMS, 2006.

Subadi Tjipto, Metode Penelitian Kualitatif, Cet. I, Surakarta : MUP UMS, 2011.

Sugiono, Metode Penelitian Kualitatif Kuantitatif Dan R\&D, .Bandung: Alfabeta, 2008.

Sumar'in, Strategi Manajemen Risiko Pada Pembiayaan Murabahah (Studi Kasus BTN Syariah Yogyakarta Pada Produk KPR Periode 2009), Tesis, Yogyakarta: UIN Sunan Kalijaga 2010.
Sutaryono, Paul, Manajemen Risiko Operasional dan Upaya Mengatasi Pembobolan Bank, Artikel Kompas, Edisi Jum'at tgl. 23 Mei 2003.

Trianti Khoiriyah, 2014, Manajemen Risiko Pembiayaan Mudharabah (Studi Kasus Bank Muamalat Indonesia Cabang Malang), Jurnal Ilmiah FEB Universitas Brawijaya Malang Zulkifli, Sunarto, Panduan Praktis Transaksi Perbankan Syariah, (Jakarta: Zikrul Hakim, 2003. 